Article

\title{
Views on Spirituality in Old Age: What Does Love Have to Do with It?
}

\author{
Linda Rykkje \\ Faculty of Health Studies, VID Specialized University, 5009 Bergen, Norway; linda.rykkje@vid.no \\ Received: 15 November 2018; Accepted: 18 December 2018; Published: 22 December 2018
}

\begin{abstract}
This paper addresses the importance of providing spiritual care for older people within the context of nursing. Based on the author's doctoral thesis, the importance of love in relation to spirituality and spiritual care will be discussed herein. The methodology is based upon Gadamer's hermeneutical philosophy, and the included material is one qualitative metasynthesis, interviews of 17 older people, a research synthesis of articles concerning connectedness and love, and a book by Paul Tillich. Love in connectedness was found as a universal force in spirituality, and different forms of love emerged in relation to spiritual needs in older people care. Furthermore, love as a re-unifying and connecting force may foster confirmation of human worth and dignity, enable serving others in reciprocate love, longing towards being part of something larger than oneself, and holiness in the sense of pursuing existential meaning or religiousness.
\end{abstract}

Keywords: spiritual care; love; old age; dignity; confirmation; serving; longing; holiness

\section{Introduction}

Nursing care has a long tradition of embracing care for the whole human being, body, soul and spirit (Lindström et al. 2010).

Ever since I became a nurse, my main interest has been to care for older people. Therefore, my first job was at a nursing home. However, it was challenging to discover that the work did not resemble what we were taught at school about holistic patient care. I found that most of my time was spent on taking care of patients' basic physical needs, while there was much less time available to meet their psychological or social needs. In particular, spiritual needs were neglected-they were, in my opinion, either invisible or not tended to at all. I remember one patient who asked me to read for her a passage in the Bible. She said she often felt anxious about her life, wondering if she had lived it 'well enough', that is, according to what her Christian faith required. I wrote a nursing problem in the patient's journal about additional spiritual needs and suggested that the appropriate nursing intervention was to read a minimum of once weekly with her from the Bible. Little attention was given to this particular problem in the nursing care plan. Although one nurse credited me for being so bold as to write about such a problem, we never talked about spiritual issues at the workplace.

Many years later, as I planned my doctoral work in caring science, I chose to focus upon spirituality and the care of older people's spiritual needs. The starting point for the research (Rykkje 2014) was that aspects of human spirituality might form a foundation for fostering dignity in old age. 


\subsection{Theoretical Framework-The Horizon of Understanding}

The thesis was based upon caring science and the theory of caritative caring by Katie Eriksson (Lindström et al. 2010). This research tradition highlights a strong ethos ${ }^{1}$ that underscores the need for research on caring to seek the truth, the beautiful, the good and the eternal in its quest to comprehend that, which lies at the core of caring (Eriksson et al. 2006).

The deepest ethical motive for all care is respect for human dignity (Eriksson 2002). Hence, the purpose of caring is to foster health and alleviate suffering in order to ensure human beings' sense of dignity and worth (Eriksson 2005; Lindström et al. 2010). My understanding is that the aim of nursing care is not to completely remove the patient's suffering; rather, caring means that the patient experiences a sense of health consistent with bearable suffering. Furthermore, when suffering is understood as a meaningful experience in human life, caregivers can help patients reach a greater insight into their own spiritual needs (Råholm et al. 2002).

When seeking new knowledge in caring science, it is important to indicate the researcher's horizon of understanding. The foremost basic assumption is that the human being is a unit of body-mind-spirit. Another key assumption is that the human being is a religious being, but that not all humans have embraced this dimension. Moreover, the human being is viewed as holy, and dignity means accepting the human obligation of serving with love and existing for the sake of others (Eriksson 2001; Eriksson and Lindström 2000; Lindström et al. 2010).

The unity of body, soul and spirit is a manifestation of the human being as a whole; thus, it is indivisible. Regarding the human spirit, we can—according to Lassenius (2005)—place the formation of the spirit in the inner core or spaciousness of human beings, portrayed as the spiritual home. My understanding of the spirit is that human beings seek wholeness, but that we also seek something transcending ourselves, such as a greater power or meaning in life.

According to Eriksson (2018), the vitality and courage to live is rooted in the human being's experience of dignity and holiness. Moreover, experiencing holiness presupposes that the human being is in contact with his or her inner core, spirituality and religiousness (Eriksson 1997, 1998). Sivonen (2000), in her own research, proposes that health and suffering depend upon human spirituality. Furthermore, attending to the human spirit demands openness and respect for fellow humans, their personal meanings, inner reality, religion or faith, and philosophy of life. In my opinion, both spirituality and religiosity, in the meaning that 'all human beings are religious beings', are connected to an understanding of life as holy and human dignity as sacred. On this view, religiousness is not limited to Christianity or another religion, and spirituality comprises more than religious matters. My understanding is that the ability to transcend (go beyond) ourselves is part of the spiritual dimension, as are existential considerations and awareness of that which gives life meaning.

The human being holds the potential for holiness in the sense that every human being has a unique and inviolate intrinsic value and that all humans have equal value. Thus, holiness is innate in the human being's absolute dignity. Edlund (Edlund 2002; Edlund et al. 2013) holds that absolute dignity embraces being whole, holiness, human worth, freedom and responsibility, duty and serving others through caring acts. Edlund also points to dignity as a relative entity, meaning that its source of value is cultural and based upon the individual's inner values and outer surroundings. My understanding is that taking care of the whole human must include the spiritual dimension, and that this is a prerequisite for safeguarding human dignity. Early in the research process, I came across Tillich's (1954) notion of love as a driving force in life; this became an important part of the analysis towards a deepened understanding of spirituality and dignity. Love, per Tillich, is a reuniting force among human beings and a resource in search for wholeness and becoming in health.

1 Ethos in caring science is described in Eriksson (2018, pp. 9-16). 


\subsection{Research about Spirituality and Spiritual Care in Old Age}

Spirituality is recognised as important in holistic care, especially when caring for ill and suffering patients (Burkhart and Hogan 2008; Creel and Tillman 2008; Ledger 2005; Pesut 2008; Sessanna et al. 2011). Research on spirituality in nursing started in the 1990s and has increased considerably since then (Reed 1992; Sessanna et al. 2007). Four main themes are central to this pursuit; (a) religion; (b) purpose and meaning in life and connectedness with others; (c) non-religious life views and values; and (d) metaphysical or transcendent phenomena.

Spirituality in nursing has been difficult to define (Fawcett and Noble 2004; Pesut and Reimer-Kirkham 2010; Swinton and Pattison 2010). Internationally, the concept of spirituality, and especially the integration of religion into this construct, have been intensely debated, with many variant views (Clarke 2009; Paley 2009; Pesut et al. 2008). Another challenge addressed by several recent studies (Austin et al. 2017; Cone and Giske 2016; van Leeuwen and Schep-Akkerman 2015) is that putting spiritual care into practice depends upon a staff's competence and awareness of spiritual issues.

Research about older people point to the health benefits of spirituality and religion. Spirituality can be a framework in daily living and a resource that supports positive ageing, and strengthen bodily and mental well-being and peacefulness, especially when older peoples' health deteriorates (Candy et al. 2012; Ennis and Kazer 2013; Lavretsky 2010; Malone and Dadswell 2018; Toivonen et al. 2018; Wallace and O'Shea 2007; Whitehead 2018; Zimmer et al. 2016). Lavretsky (2010) claims that older people with a religious life view can find greater well-being than nonreligious people, as religious affiliation supports social relationships; moreover, religion can provide the answer to universal questions related to loss and death, as well as contribute to the maintenance of meaning in life. A Norwegian study among 242 persons aged $75+$ years who received home nursing (Dale et al. 2010) found that approximately $80 \%$ of participants reported religion as personally important and, further, found that religiosity and purpose in life were positively associated.

It is important to ground spiritual care within daily life, however, it should be based on older people's own perceptions and viewpoints (MacKinlay and Hudson 2008). Because both older people themselves—as well as their relatives and health care personnel—often view nursing homes as close to end of life, it is equally important not to focus upon dying in that context (Touhy 2001). Rather, the nursing facility should be a home where older people can continue to develop their spirituality and realise their full potential as human beings.

\subsection{Research about Dignity in Old Age}

Research about dignity has been ongoing since the 1960s (Whitehead and Wheeler 2008). Respect for human dignity is central in nursing care (Baillie and Gallagher 2011). The interest in dignity in healthcare has increased of late, especially in the context of health politics regarding elder care (Manthorpe et al. 2010; Nordenfelt 2003; Tadd et al. 2002). In Norway there is a regulation called the 'dignity guarantee' (Ministry of Health and Care Services 2010), which states that health care should provide a dignified, safe and meaningful life in old age.

The challenge in dignity research is that there is a lack of consensus about the content of the concept itself (Gallagher 2011). It has been claimed that dignity as a construct is useless and should be replaced by such notions as respect and autonomy (Macklin 2003). Despite the ambiguity of the concept, simply discarding it would be a mistake (Sulmasy 2013). Indeed, it is a danger that if we do not understood dignity properly, its meaning may disappear behind other priorities in health care (Shotton and Seedhouse 1998).

Older people consider dignity as important in everyday life, relating it to self-esteem, being valued and wellbeing (Bayer et al. 2005). A recent literature review of dignity research (Šaňáková and Čáp 2018) found that older patients value autonomy and control, privacy, relationships, care and comfort, communication and identity. Attentiveness, respect and trust are important aspects of dignity in the perspective of nursing homes residents (Dwyer et al. 2008; Franklin et al. 2006; Heggestad et al. 2015; Oosterveld-Vlug et al. 2014). Nursing facility residents also have emphasized 
inner strength and coping, autonomy, and to be met as an individual person with his or her unique life history. Similar views of dignity in old age can be found in home health care and in acute hospital settings (Gregory et al. 2017; Hall and Høy 2012; Tauber-Gilmore et al. 2018).

When older people need help, they are vulnerable to loss of dignity and integrity (Stabell and Lindström 2003) —and with this—can experience feelings of shame about being old, sick and tired. In addition, if older people meet negative attitudes in society or fear their individual needs are not being met by healthcare personnel (Harrefors et al. 2009; Oosterveld-Vlug et al. 2014; Pleschberger 2007), their sense of worth and dignity can be diminished.

A challenge in nursing is that, although the staff generally wish to provide dignified care, lack of resources may reduce their ability to transform the ideal of dignity into practice (Baillie et al. 2009; Jakobsen and Sørlie 2010). Dignified care means that nurses are interested in knowing the individual patient; however, dignity also depends upon how the individual person values him or herself. According to Hall and Høy (2012), care for older people has to do with creating small situations in everyday life, in which each individual can experience a sense of dignity; by these means, he or she can thrive.

\section{Love in Connectedness-A Key Finding}

The doctoral thesis (Rykkje 2014) on which this paper is based consisted of three sub-studies: Sub-study I was a qualitative metasynthesis; Sub-study II was an interview study of older people; and Sub-study III was a theoretical paper about love and connectedness. Love in connectedness was a key finding throughout the work and, in fact, is a universal force found in both spirituality and human dignity.

\subsection{A Qualitative Metasynthesis of Spirituality}

Sub-study I (Rykkje et al. 2011) found connectedness with inner space at the center of human spirituality. This category partly overlaps and interacts with four more categories; connectedness with higher power, connectedness with nature, connectedness with others, and connectedness with community. Interestingly, love in connectedness was found as an ontological core category and a motivating force in spirituality. This indicates the presence of universal love in human experience. Love, it may be said, serves as the 'binder' that enables one to form durable connections with self and others, community, nature, and a higher power. Thus, love motivates spiritual thoughts and actions, fosters inner strength, and is present in caring relationships and caring acts. Inherent in love we find compassion, concern, being seen, and being confirmed as a human being. Broadly, we can portray spirituality as 'love in action':

The best way I can define it, for myself, is like love in action. You don't have to be Christian to know love. We pick up on the love ... love is present in the environment ... There is love behind any action that we do. (Lewis et al. 2007, p. 18)

\subsection{A Qualitative Interview Study of Older People}

Love in connectedness emerges through phenomena in people's lives. In Sub-study II (Rykkje and Råholm 2014; Rykkje et al. 2013) older people ${ }^{2}$ were interviewed; love was found to be important in understanding the elements of dignity, spirituality, and spiritual care. In this study, the participants portrayed their philosophy of life in line with the Norwegian Christian cultural heritage (Engedal 2011; Rykkje et al. 2013); within this tradition, values such as love of neighbor

2 The 17 included participants were 74-96 years old, six men and 11 women. Six participants did not receive healthcare services; five were home healthcare recipients; six were nursing home residents. 
and equality are prominent. For these participants, love in the sense of caring about ${ }^{3}$ oneself, others, nature or God, was an essential phenomenon in their lives. Spirituality encompasses longing to both give and receive love, experiencing faith and hope, and feeling that life has meaning (Eriksson 2001). To care about was grounded in the participants' understanding of dignity as having value as a human being-this means that value is fostered when a human being can provide compassionate care in relation with others, and that others return this affection.

Therefore, connectedness is based upon reciprocal love-in the sense of the anticipation for both giving and receiving something in return (Rykkje and Råholm 2014). In old age, frailty and illness may reduce the possibility to give, and many older people find themselves to be mostly receiving. Connectedness with nature and a higher power (e.g., God), however, are spiritual areas where many older people retain their ability to give; one example is to pray for others. There is also the hope that loving relations endure as one grows older, that older people can still give love to family and friends-a hug or kind words have no age limits. Regarding health care personnel, there is a difference between the love expressed in family relations as opposed to professional relations. However, regarding spiritual care, it is important that health care personnel show that they care about their patients. This is in line with the notion that nurses who care for the patient also have genuine desire to see the patient (Karlsson and Bergbom 2010). We can glimpse the significance of love in these two interviewees' views of spiritual care in a nursing home:

Just to be present with the patient can be enough care ... And not least touch; to touch them-and talking with them. Then, then we speak about care ... The most important, however, is that the person who enters the patient room is someone who really cares about the person lying in the bed. (Participant A)

I believe you must see the human being who sits or lays there; you must in a way ... A nurse cannot spend all her time in situations where the patients need someone to talk to-perhaps for half an hour. Of course, there is a limit... Then again, I think a nurse or an assistant that have a relation with the patient, that they do not forget the person when they leave the room. Thinking later-now I have the time to pop in and have a chat with the person, I mean-the nurse can adjust... They must not walk out the door and then I am forgotten, that the patient is forgotten. (Participant B)

In these statements, we can recognise the importance of nurses who care about their patients in the sense of being present, seeing them as a person, touching and thinking about them, and remembering their individual caring needs.

\subsection{A Theoretical Study of Love in Connectedness}

Sub-study III (Rykkje et al. 2015) searched for a deeper understanding of love and connectedness, through a theoretical literature review. This investigation found that connectedness is a concept of great significance inherent in human spirituality and which serves as a unifying force. Love is a key notion in caring for patients; however, there are many types of love, and differences exist in how to comprehend it. The sub-study centers upon compassion and the risk of losing love in patient care. Compassion for the suffering human being has shaped caring for hundreds of years (Thorkildsen et al. 2013). von Dietze and Orb (2000) portray compassion as to suffer with; thus, it is quite relevant in connectedness with others. Furthermore, compassion is to avoid paternalistic care and must not be misunderstood as pity. Compassionate care is:

3 The expression to care about or care for someone is in Norwegian bry seg om and implies a loving or warm relation. Karlsson and Bergbom (2010) point out that nurses who do not care for imply that the patient is unimportant and is someone who annoys the nurse. 
not simplistically about taking away another person's pain or suffering, but is about entering into that person's experience so as to share their burden in solidarity with them and hence enabling them to retain their independence and dignity. (von Dietze and Orb 2000, p. 169)

Love has seemingly had lean times in patient care. Several authors (Rykkje et al. 2015, p. 7) suggest that love or compassion may sound threatening and unprofessional and, further, that love is an inferior value in caring - a weakness, or even a taboo. Caregivers who love in the practice of caring are often viewed as going beyond the role definition and their duty of care (Fitzgerald and Hooft 2000). Hence, Straughair (2012) claims that the nursing profession has lost some of the ethos of compassion in favor of technical skills based heavily on evidence-based practice. However, when caregivers are genuinely concerned for the patient, love is evident, and the prospect for healing may increase (Stickley and Freshwater 2002).

This study also built upon a book by Tillich (1954), who portrays love as the driving force and constitutive element of life, encouraging all that is separated towards unity. Thus, love is understood as a reuniting and connecting force, both towards one's inner self as a human being and in the search for connectedness towards something or someone outside oneself. Consequently, love must be a fundament in both connectedness with oneself as well as in connectedness with others. Moreover, love has the capacity of movement beyond the limitations of an individual standpoint and surrender to a greater reality-moving towards greater harmony and unity (Kenny 2011). Therefore, love is also a fundament in connectedness with something greater than oneself.

\section{Love in Connectedness-A Dynamic Power in Four Forms}

There are different kinds of love. In caring science, caritative care is central; caritas represents altruistic love and are the motive for caregiving (Levy-Malmberg et al. 2008). In my work, my focus on caritas is understood as love of neighbor, compassion and mercy. The love of neighbor is found in the expression to care about other human beings. According to Cody (2002), love of neighbor is an ethical principal in caritative care, represented in the notion of unconditional love. I understand caritas not as a duty required by others, but rather an inner motivated strength and appeal to protect life's vulnerability, both in ourselves and in others.

Love in connectedness is a universal and dynamic power inherent in both spirituality and dignity; as such, it is a potential health resource. Love in connectedness originates from an ethos that safeguards the whole human being; it appears in relationships that embrace reciprocity between people who care about each other. The thesis portrays love in connectedness as a dynamic power in four forms:

(1) A life-giving source and a basic element in life itself, influencing the spirit and inner space of human beings through love of oneself

(2) An ethical guide for action through creative listening, giving and forgiving, pointing to reciprocity in love for others, and love can provide direction and content to understanding of spiritual care

(3) A force in the search for reunification with life's infinity, represented by love beyond oneself, and love is regarded as present in human religiousness-a central value in human dignity

(4) Love of fellow human beings is a force that originates from the ethos of love that safeguards the whole human being and his or her inherent dignity

Moreover, love as a reunifying and connecting force may foster confirmation, serving, longing and holiness. I will explore this further in the following four sections.

\subsection{Confirmation}

My research started with the notion that there may be aspects of the human's spiritual space that form a foundation for the maintenance of human dignity. The findings of this thesis point to the presence of an ethos that values the human being and confirms human dignity. This is reflected in love in connectedness through the phenomenon of love for fellow human beings. This type of love corresponds 
to altruism and love of neighbor, as found in Norwegian humanistic values based within our Christian cultural heritage (Rykkje et al. 2013). Fitzgerald and Hooft (2000) note that this kind of love requires the willpower and commitment to wish good for the other before ourselves and without demanding anything in return. Values and moral attitudes, according to Nåden and Nåden and Eriksson (2004), hold great importance for safeguarding human dignity. Hence, caregivers must base their work on values grounded in caritative ethics (Heijkenskjöld et al. 2010).

An ethos of love that forms compassionate care and concern for others may enhance the patients experience of intrinsic value and dignity. When the patient is in touch with his or her spirit or inner space, dignity can be confirmed by the recognition of his or her own value as a human being. However, as patients often face anxiety and suffering, they may feel their relative dignity is threatened. A prerequisite for experiencing dignity is the power of love through love of oneself or self-compassion. This form of love comprises experiencing connectedness and ability to care for oneself, and such love of self can contribute to alleviating suffering (Reyes 2012). Older people find that spirituality is vital, as being in touch with inner space may foster the feeling of peace and calm, wholeness and health (Rykkje and Råholm 2014). Accordingly, becoming in health is related to experiencing wholeness (Eriksson 2007). In conclusion, inner peace and wholeness, together with self-compassion, may provide the individual patient the courage to value his or her own worth as a human being and thus feel confirmation of his or her dignity.

\subsection{Serving Others}

This thesis holds that people's ethos and philosophy of life should be based on values such as equality, human worth and compassion; with such values, one can actualise love's inherent desire to serve others-wanting what is best for the other being. Although love of neighbor and compassion are accessible for all, they can be valued by some and rejected by others (von Dietze and Orb 2000). Compassion as a value, however, is important in nursing care and essential for maintaining the patient's dignity.

Serving in love is understood as compassionate care for one another, based on reciprocity. This reflects the caring science assumption that dignity means accepting the human obligation of serving with love and existing for the sake of others (Lindström et al. 2010). I consider love for fellow human beings as universally present in the world, though not all humans utilise this force in the sense of serving in love for each other.

The relationship between spiritual care and dignity can be seen in the experience of wholeness, where care for the whole person, including the spiritual dimension, is understood as a prerequisite for perceived dignity. Spiritual care includes activities affiliated with religion, being in contact with nature (i.e., being outdoors, plants and pets), and other individual interests such as art, hobbies or music. In addition, spiritual care includes how family and health care personnel show their love and care about the patient, through the power of love for others. Older people wish for reciprocity in their relationships, as they desire to serve their family and loved ones as long as possible. However, this might also apply for the nurse-patient relationship. When nurses allow the older person to give, perhaps by expressing appreciation for receiving care, this opens up the potential for mutuality. This is essential because being able to give and receive love may contribute to experiencing that one's life has meaning-here and now (Lindström et al. 2010). Relative dignity can be altered when facing illness, suffering and loss, but the way care is provided may mitigate experiences of diminished dignity due to frailty and dependence on others. This implies the importance of relationships between people and their underlying values, as well as the atmosphere of the care setting. In the caring encounter, to serve others in love is considered a basic value.

\subsection{Longing}

The results of my thesis imply that religion must be an integral part of human spirituality; this view is based on my understanding of religiousness. Eriksson (2001) holds that human beings long 
to be part of a greater communion with others and with God. Being part of something larger than oneself, as found in connectedness with a higher power and connectedness with nature, is part of the human search to understand the world in which we live (Eriksson 2010). This is essential in how I understand religiousness; love beyond oneself may be a force in this search process.

In spiritual care, we can meet patients who are longing for answers to the larger questions in life: severe illness and fear of death may put forward the question of life's meaning. Suffering is often related to accepting the reality of death; this can trigger the desire and search for a higher power (Ferrell and Coyle 2008). Health problems, pain and illness may initiate existential questions, and patients may interpret their suffering in light of a religious view of life (Tornøe 1996). The findings indicate that religious support should be offered when appropriate, although there should be a balance in spiritual care with regard to individual patient's beliefs and desires (Miner-Williams 2006; Ross 1997; Sartori 2010; van Leeuwen et al. 2006).

Furthermore, the study findings reflect a longing for being part of a community in connectedness with others (Bellingham et al. 1989; Register and Herman 2010; Younger 1995). This may include loved ones and, particularly family and friends, as well as acquaintances who are more peripheral; it may also entail being part of a group, a culture, the society or even the world. Connectedness means a sense of membership and belonging in the human community and a recognition of unity between oneself and others. Love is an attribute for connectedness in social relationships, through caring, affections, warmth, and concern for others' well-being (Phillips-Salimi et al. 2012).

\subsection{Holiness}

In religiousness, there is a longing for connectedness with a greater meaning; through love beyond oneself, a presence of infinity and holiness may emerge. Religiousness can be one way of expressing the human perception of a holy cosmos in which one can be confronted with an infinite power transcending life and our existence (Clarke 2009). Holiness becomes part of life's mystery and is found in the human being's meeting with that which is perceived as divine (Otto 1958). Moreover, holiness can involve a longing for a higher power or existential meaning (Baldacchino and Draper 2001).

Holiness is seen in the human being's possession of an inviolate intrinsic value (Eriksson and Lindström 2000). Furthermore, Eriksson $(1997,2010)$ proposes that health is related to unity and holiness, and that holiness is a source of faith and hope-which, like love, are basic sources of strength throughout life. Experiencing holiness presumes that the human being is in contact with his or her innermost core, spirituality and religiousness (Eriksson 1998), which is reflected in the spiritual space of the individual. Love of oneself can be viewed as a source of inner strength and transcendence that may foster spiritual growth (Eriksson 1990). Thus, love can become a resource for understanding existential questions concerning life and death (Thorkildsen et al. 2013).

When patients encounter illness and suffering, they often search for meaning and purpose in their own life (Råholm and Eriksson 2001; Younger 1995). The findings in this thesis suggest that the patient can find balance in his or her being and may reach an acceptance of his or her situation. The process of loving oneself and accepting the present situation can be a lonely journey, as it requires quiet moments of solitude (Rykkje et al. 2011). Love of oneself is essential because a human being who does not see him- or herself as valuable or believe in higher values can find it hard to experience meaning (Barbosa da Silva and Persson 1991). The experience of connectedness in life may foster the human being's notion of dignity and holiness and may therefore appear as an active force in search for wholeness and becoming in health.

\section{Care for the Whole Human Being}

The findings point to the importance of caring for the whole human being, including the spiritual dimension of life. In this section, I will focus upon how my findings may contribute to spiritual care and dignity in older people nursing. I will also argue that love has much to do with it. 


\subsection{Spirituality in Old Age}

It is important to understand that there are many interpretations and views of spirituality. One woman from the interview study described her spirituality as follows:

There are so many varieties of spirituality ... a good conversation. To go outside-a morning, birds sing, it is quiet ... and this with the children, of course. Otherwise-good conversations with friends ... When you think about spirituality, then I think somehow of God. (Participant C)

A broad understanding of what spirituality might be in old age was common among the interviewed participants; this view of spirituality is in line with the findings of the metasynthesis of Rykkje et al. (2011). This means that nurses must have an individual approach to each older patient, to meet their particular spiritual needs and desires (Sivonen 2000).

\subsection{A Dignified Old Age and the Value of Loving Relationships}

From the interview study, a more comprehensive understanding of dignity in old age emerged. Central to dignity is feeling valued and appreciated, and results suggest that family and friends often are 'the most important' in older peoples' lives. There were also examples of the interconnectedness of a dignified old age and spiritual care. The following quote is illustrative:

The material things - they live well, sit comfortably, the environment is positive, and they feel fine ... They are given food and all that; care and visits and family ... The material things must be in place ... But then you have something spiritual ... the priest might have something to add ... and music and art, and they experience something like that ... A dignified old age - the family appears as well, to this that may come in addition ... They must feel they still—they are not abandoned. Feel they still exist and, and, really. They are not only positioned there to die ... they must feel alive. This is a sum of all these things mentioned. (Participant D)

In Norway, the municipalities are responsible for providing long-term care, and the government has an interest in ensuring dignified care for older people (Ministry of Health and Care Services 2010). Nevertheless, Norwegian researchers find that municipal home-based services are a complement, rather than a substitute, for family care (Dale et al. 2011). The participants in my study valued living independently and often depended on family support when in need of help. However, they also wanted public assistance in order to feel they did not burden their family. Thus, municipal care services should assist when older people require assistance with basic needs such as personal hygiene, nutrition or health problems caused by chronic illness or frailty. The family, then, has another yet very meaningful assignment: they must be there for the older person and show their love and that they care about him or her. Thus, in old age, loving relationships with family and friends are of great importance (Harrefors et al. 2009; Pleschberger 2007).

Dignity is associated with a sense of confirmation of human worth (Eriksson 2001; Lindström et al. 2010). My reflection is that being with others and conversations may provide a sense of confirmation to the older patient, that he or she still matters-thus, even small talk or chats foster dignity. Several participants spoke about the importance of having someone to talk to, as found in this older man's statement:

Just sit down and talk for five minutes. First, it helps her or him you talk to, and secondly-look at them after they have talked with someone-they shine like the sun ... It has all to do with dignity. Because if you have someone to talk to, and you understand each other, then the person in the nursing home-is being, this he thinks about afterwards, many times, and then he feels very fresh. Because it was someone who cared ... and that means a lot. (Participant E) 
It is the family that is expected to visit patients; however, many relatives are busy, and most patients do not receive visits every day. Nurses cannot replace loving relationships with relatives, and it is certainly not my intent to suggest they should. Yet, not all patients have close relations with their relatives: some patients are alone with small or no network of family or friends. In such situations there is the possibility of engaging volunteers; indeed, this is one of the governmental strategies for providing better patient care (Haugen and Logstein 2016). However, in my opinion, there should be sufficient room for nursing personnel to engage in small talk in the daily care provided to older people.

\subsection{Spiritual Care and the Importance of Everyday Chats}

Spiritual care in old age could provide the opportunity for patients to attend activities, exercise or hobbies, be with family, or participate in religious activities (Rykkje and Råholm 2014). In my conversations with older people, we have talked about many individual needs and experiences. I remember one participant in the interview study who said that spiritual care was the same as care, because care was to see the whole human being and care about the patient. This is how the older man portrayed what he understood as spiritual care:

It can be spiritual care when you have a bedfast, sick patient, and you [as a nurse] take the patient's hand and talk to him. Is not that spiritual care? I want to believe that. And if you manage to get in touch and talk to them, about anything really-but they feel your closeness, when you sit there and hold their hand. You might say that you are coming back to them tomorrow; then they have something to look forward to as well. (Participant F)

This confirms the presence of love as a dynamic human energy, which touches soul and spirit of both the patient and the nurse (Goldin 2018). Based on what is important in everyday life of older people, it is talking to others that seems to be the most significant nursing intervention. Many of the interview participants told that they missed the everyday chat with others. As many older patients rely on help from nursing personnel, they pointed to how personnel both in home care and in nursing facilities were busy, and appreciated those few minutes where nurses sat down and talked, and not just performed tasks. My interpretation is that everyday moments of conversations can provide meaning and joy, and may help confirm the older patient's value as a person.

\subsection{Spiritual Conversations about Religion and Existential Matters}

A common opinion among the older people interviewed was to associate spirituality with religion (Rykkje et al. 2013). This does not mean that all participants were religious, but all were brought up in a society where Christianity were part of their primary school teaching and integrated into life-events such as baptism, weddings and funerals. Participants with a strong religious affiliation often had religious support from family and friends, although a few nursing home residents wished for religious support outside their family_from someone who understood their religious position. According to Eriksson (1997), nurses should recognise and meet patients' spiritual needs, irrespective of their own attitude towards spirituality and religion. The participants endorsed the view that, if nurses feel unable to talk to the patient themselves, their professional duty is to refer the patient to another person who can be of help (Ledger 2005).

Furthermore, I would like to consider the patients with modest or low religious affiliation. In my study, several participants said that their childhood fate helped them to come to terms with what will happen after death. Religious practices from youth and adulthood are brought into the ageing phase of life (Bondevik and Skogstad 2000; Høeg 2010). Thus, the often latent faith of the older person may, in old age, come to the fore and provide sufficient answers to existential questions of death and afterlife (Torbjørnsen 2008). Being closer to death, some individuals, however, struggle with their existential thoughts; in this regard, I will present the story of a nursing home resident, given the fictional name Olga. 
When talking with Olga, she expressed that she did not know much about spirituality. Nevertheless, several times in our conversation, she spoke about her concerns about not being a 'really good Christian'. When she was alone, she thought about existential matters: 'I have thought about that I will not join the good team'. Olga said that her life had been good, with few economic worries. Her concern was:

I've always thought that it might not be much chance for me that has been so spoiled ... That there is no room for me afterwards ... I'm not thinking about it that much ... These are such small things, material things I do not think I've done right ... I think I'm not good enough in a way. I think of that often. (Participant G)

When I asked Olga if she had someone to talk to about her concerns, she said that one of the employees would sometimes comfort her and 'talk about a bit more serious matters, in a nice and not difficult way'. Olga said that she did not discuss these matters with others, and that it was not easy to reach out because the staff were busy. To recognise the need to talk about death and afterlife can be challenging for nurses; they must have knowledge and be aware of religious and spiritual needs (Austin et al. 2017; Cone and Giske 2016; van Leeuwen and Schep-Akkerman 2015). Another challenge is that the patient must experience trust in the relationship in order to feel comfortable speaking with someone about his or her personal thoughts. When asked if she would like to talk to a member of the clergy, Olga said she had not thought about that option. She did seem open to the idea, saying: 'It is so many strange thoughts, but I guess everyone has them, because we do not know just how, and what will happen [after death].' However, she also said that she did not feel a need to discuss her worries, although she repeated her concerns:

It is those thoughts you have when you lay in bed alone, then all the thoughts come along, you know ... I am just an ordinary person ... But I have always thought, in the back of my head, that I am not good enough. Because-I do not do any particular bad stuff, but I do not do terribly much good either. I feel by myself that I am no quite good enough, kind enough. (Participant G)

My reflection is that it is not easy for personnel to recognise the need for conversations about existential matters in patients like Olga, because of her uncertainty about her needs and the indirect words she used to describe her existential concerns. However, we as nurses should always get to know our patients sufficiently well to become aware of their spiritual needs and desires. Religious beliefs can be a resource when meeting difficulties in life: for some of the interviewees, their faith in God supported them, for others, the support came from clergy or from attending religious rituals. These results suggest that religion can contribute to experiencing meaning in life as well as the prospect of an afterlife; for some, it can alleviate suffering. Therefore, spirituality and religiousness can contribute to wholeness and becoming in health (Eriksson 2007).

\subsection{The Significance of Love within Spirituality and Dignity and the Need for Future Research}

Based on the interviews (sub-study II), I understand that it was an important part of spiritual care to receive love from family and friends through visits and expressions of concern; these relationships were often the main resource for meaning in life. A longing for being part of human relationships (Eriksson 2001) is still vital in old age. Love is the key for connectedness with others, through caring, affection, warmth and concern (Phillips-Salimi et al. 2012). Serving in love and existing for the sake of others (Lindström et al. 2010) was a value underpinning the significance of relationships based upon reciprocity and rooted in genuine concern, for example, that visits were reflective of love as opposed to obligation. Several participants said that they were afraid of being dependent upon others, especially when living in a nursing facility, they feared the family would forget them. Furthermore, it was essential that health care personnel see the individual human being; most important was the experience that people cared about them. Based on the interviews, the essence of fostering dignity 
in old age is being confirmed by experiencing being loved, not forgotten, and feeling alive through spiritual care.

Nurses cannot substitute for family visits and care from loved ones, because of the differences in the quality of the relationship pertaining to love. However, my thesis suggests that nurses must provide compassionate care in the sense to care about the other person. Thus, we need more knowledge about the attitudes and behaviors that lead to improved patient-reported outcomes based on compassionate care, and especially more research where patients' and their families' voices are obtained (Sinclair et al. 2016). There is also a need for supportive culture in organisations with an atmosphere conducive to compassionate care (Valizadeh et al. 2016). Although compassion is a component of the quality health care nurses are expected to provide, there are still personal, relational and systemic challenges concerning compassionate care (Singh et al. 2018). According to Taylor et al. (2017) there is need of further research aiming to develop and implement compassion within healthcare, through recognition, connection, altruistic desire, humanistic response and action. I believe a better understanding of the process of compassion as a motivating force for both patients as well as nurses (van der Cingel 2011) can strengthen the ability to work together in achieving relevant outcomes of care according to the individual patient's needs and desires.

\section{Materials and Methods}

The methodology in this thesis was based upon Gadamer (2004) hermeneutical philosophy, and the research process was a movement in the hermeneutical spiral in which the three sub-studies were built upon each other. Thus, new research findings contributed to a broadened understanding of the previous sub-studies. This paper presents both the research process and the sub-findings, as well as new thinking patterns that emerged from the synthesis of the research results as a whole.

The included material is one qualitative metasynthesis (sub-study I) based on 17 empirical articles, interviews of 17 older people (sub-study II), and theory development (sub-study III) based on a research synthesis of articles concerning connectedness and love, and the book Love, Power and Justice by Tillich (1954).

The doctoral study was approved by the Regional Committees for Medical and Health Research Ethics (Ref. 2010/2677a). Interview participants were informed both orally and in writing about the study purpose, the possibility of withdrawal and confidentiality procedures, in accordance with the Declaration of Helsinki (WMA (World Medical Association) 2013).

\section{Conclusions}

Based on this thesis, love in connectedness as a reunifying force may contribute to realising the human being's spiritual potential. The thesis supports the view that caring for the whole human being must include the spiritual dimension. It is important for one to be seen as an individual human being, one who is loved by people who care about you. Furthermore, the findings suggest that a dignified old age implies not feeling lonely or abandoned, but rather feeling loved and alive through compassion and spiritual care, personal development and thriving, as well as spiritual wellbeing.

Funding: This research received no external funding.

Conflicts of Interest: The author declares no conflict of interest.

\section{References}

Austin, Philip, Roderick Macleod, Philip Siddall, Wilf McSherry, and Richard Egan. 2017. Spiritual Care Training Is Needed for Clinical and Non-Clinical Staff to Manage Patients' Spiritual Needs. Journal for the Study of Spirituality 7: 50-63. [CrossRef]

Baillie, Lesley, and Ann Gallagher. 2011. Respecting Dignity in Care in Diverse Care Settings: Strategies of UK Nurses. International Journal of Nursing Practice 17: 336-41. [CrossRef] [PubMed] 
Baillie, Lesley, Pauline Ford, Ann Gallagher, and Paul Wainwright. 2009. Nurses' Views on Dignity in Care. Nursing Older People 21: 22-29. [CrossRef] [PubMed]

Baldacchino, Donia R., and Peter Draper. 2001. Spiritual Coping Strategies: A Review of the Nursing Research Literature. Journal of Advanced Nursing 34: 833-41. [CrossRef] [PubMed]

Barbosa da Silva, António, and Marita Persson. 1991. Lidandets mening i ljuset av livets mening [If Life has No Meaning or Value, Then has Suffering No Meaning or Value]. In Vårdteologi [Caring Theology]. Edited by Katie Eriksson and António Barbosa da Silva. Vasa: Department of Caring Science, Åbo Akademi University, pp. 144-203.

Bayer, Tony, Win Tadd, and Stefan Krajcik. 2005. Dignity: The Voice of Older People. Quality in Ageing 6: 22-29. [CrossRef]

Bellingham, Richard, Barry Cohen, Todd Jones, and Le Roy Spaniol. 1989. Connectedness: Some Skills for Spiritual Health. American Journal of Health Promotion 4: 18-31. [CrossRef]

Bondevik, Margareth, and Anders Skogstad. 2000. Loneliness, Religiousness, and Purpose in Life in the Oldest Old. Journal of Religious Gerontology 11: 5-21. [CrossRef]

Burkhart, Lisa, and Nancy Hogan. 2008. An Experiential Theory of Spiritual Care in Nursing Practice. Qualitative Health Research 18: 928-38. [CrossRef]

Candy, Bridget, Louise Jones, Mira Varagunam, Peter Speck, Adrian Tookman, and Michael King. 2012. Spiritual and Religious Interventions for Well-Being of Adults in the Terminal Phase of Disease. Cochrane Database of Systematic Reviews. [CrossRef]

Clarke, Janice. 2009. A Critical View of How Nursing has Defined Spirituality. Journal of Clinical Nursing 18: 1666-73. [CrossRef]

Cody, William K. 2002. Lyrical Language and Nursing Discourse: Can Science be the Tool of Love? Nursing Science Quarterly 15: 98-106. [CrossRef]

Cone, Pamela H., and Tove Giske. 2016. Nurses' Comfort Level with Spiritual Assessment: A Study among Nurses Working in Diverse Healthcare Settings. Journal of Clinical Nursing 26: 3125-36. [CrossRef] [PubMed]

Creel, Eileen, and Ken Tillman. 2008. The Meaning of Spirituality among Nonreligious Persons with Chronic Illness. Holistic Nursing Practice 22: 303-9. [CrossRef] [PubMed]

Dale, Bjørg, Hans Inge Sævareid, Marit Kirkevold, and Olle Söderhamn. 2010. Older Home Nursing Patients' Perception of Social Provisions and Received Care. Scandinavian Journal of Caring Sciences 24: 523-32. [CrossRef] [PubMed]

Dale, Bjørg, Hans Inge Sævareid, Marit Kirkevold, and Olle Söderhamn. 2011. Older Home-Living Patients Perceptions of Received Home Nursing and Family Care. Nordisk Sygeplejeforskning 1: 219-34.

Dwyer, Lise-Lotte, Lennart Nordenfelt, and Britt-Marie Ternestedt. 2008. Three Nursing Home Residents Speak About Meaning at the End of Life. Nursing Ethics 15: 97-109. [CrossRef] [PubMed]

Edlund, Margareta. 2002. Människans Värdighet-Ett Grundbegrepp Inom Vårdvetenskapen [Human Dignity—A Basic Concept in Caring Science]. Ph.D. dissertation, Åbo Akademi University, Vasa, Finland.

Edlund, Margareta, Lillemor Lindwall, Iréne von Post, and Unni Å. Lindström. 2013. Concept Determination of Human Dignity. Nursing Ethics 20: 851-60. [CrossRef]

Engedal, Leif Gunnar. 2011. Searching for Spiritual Roots and Discipleship in a Postmodern Consumer Culture: The Norwegian Crossroad Movement. Spiritus: A Journal of Christian Spirituality 11: 51-66. [CrossRef]

Ennis, Everol M., Jr., and Meredith Wallace Kazer. 2013. The Role of Spiritual Nursing Interventions on Improved Outcomes in Older Adults with Dementia. Holistic Nursing Practice 27: 106-13. [CrossRef]

Eriksson, Katie. 1990. Pro Caritate. En Lägesbestämning av Caritativ vård [Pro Caritate. A Positioning of Caritative Care]. Vasa: Department of Caring Science, Åbo Akademi University.

Eriksson, Katie. 1997. Caring, Spirituality and Suffering. In Caring from the Heart: The Convergence of Caring and Spirituality. Edited by Mary Simone Roach. New York: Paulist Press, pp. 68-83.

Eriksson, Katie. 1998. Hälsans tragedi [The Tragedy of Health]. Finsk Tidsskrift 10: 590-99.

Eriksson, Katie. 2001. Vårdvetenskap som Akademisk Disciplin [Caring Science as an Academic Discipline]. Vasa: Department of Caring Science, Åbo Akademi University.

Eriksson, Katie. 2002. Caring Science in a New Key. Nursing Science Quarterly 15: 61-65. [CrossRef]

Eriksson, Katie. 2005. Det lidende menneske [The Suffering Human Being]. Oslo: Tano.

Eriksson, Katie. 2007. Becoming through Suffering-The Path to Health and Holiness. International Journal for Human Caring 11: 8-16. [CrossRef] 
Eriksson, Katie. 2010. Se Människan [See the Human Being]. Sigtuna: Sigtunastiftelsen, Available online: www. sigtunastiftelsen.se/Artiklar_2_1053.html/lid/111515 (accessed on 2 March 2013).

Eriksson, Katie. 2018. Vårdvetenskap_Vetenskapen om Vårdandet [Caring Science]. Stockholm: Liber.

Eriksson, Katie, and Unni Å. Lindström. 2000. Siktet, Sökande, Slutandet-Om den vårdvetenskapliga kunskapen [Sight, Searching, Conclusion-About the Caring Science Knowledge]. In Gryning. En Vårdvetenskaplig Antologi [Dawning. A Caring Science Anthology]. Edited by Katie Eriksson and Unni A. Lindström. Vasa: Department of Caring Science, Åbo Akademi University.

Eriksson, Katie, Unni Å. Lindström, Anne Kasén, Lisbet Lindholm, and Dahly Matilainen. 2006. Ethos anger siktet för vårdvetenskap vid Åbo Akademi [Ethos Gives the Aim for Caring Science at Åbo Akademi University]. Hoitotiede 18: 296-98.

Fawcett, Tonks N., and Amy Noble. 2004. The Challenge of Spiritual Care in a Multi-Faith Society Experienced as a Christian Nurse. Journal of Clinical Nursing 13: 136-42. [CrossRef] [PubMed]

Ferrell, Betty R., and Nessa Coyle. 2008. The Nature of Suffering and the Goals of Nursing. Oncology Nursing Forum 35: 241-47. [CrossRef] [PubMed]

Fitzgerald, Les, and Stan van Hooft. 2000. A Socratic Dialogue on the Question 'What is Love in Nursing?'. Nursing Ethics 7: 481-91. [CrossRef] [PubMed]

Franklin, Lise-Lotte, Britt-Marie Ternestedt, and Lennart Nordenfelt. 2006. Views on Dignity of Elderly Nursing Home Residents. Nursing Ethics 13: 130-46. [CrossRef] [PubMed]

Gadamer, Hans-Georg. 2004. Truth and Method. London: Continuum, vol. 2.

Gallagher, Ann. 2011. Editorial: What do We Know about Dignity in Care? Nursing Ethics 18: 471-73. [CrossRef]

Goldin, Marlienne. 2018. Nursing as Love: A Hermeneutical Phenomenological Study of the Creative Thought within Nursing. In A Handbook for Caring Science. Expanding the Paradigm. Edited by Rosa Williams, Sara Horton-Deutsch and Jean Watson. New York: Springer Publishing.

Gregory, Anna, Shylie Mackintosh, Saravana Kumar, and Carol Grech. 2017. Experiences of Health Care for Older People Who Need Support to Live at Home: A Systematic Review of the Qualitative Literature. Geriatric Nursing 38: 315-24. [CrossRef]

Hall, Elisabeth O. C., and Bente Høy. 2012. Re-Establishing Dignity: Nurses' Experiences of Caring for Older Hospital Patients. Scandinavian Journal of Caring Sciences 26: 287-94. [CrossRef]

Harrefors, Christina, Stefan Sävenstedt, and Karin Axelsson. 2009. Elderly People's Perceptions of How They Want to Be Cared for: An Interview Study with Healthy Elderly Couples in Northern Sweden. Scandinavian Journal of Caring Sciences 23: 353-60. [CrossRef]

Haugen, Marit S., and Brit Logstein. 2016. Frivillighetens Plass i Distriktskommuners Eldreomsorg. En Forprosjektrapport [Volunteerism and Its Place in Districts' Community Care for Older People. A Pre-Project Report]. Available online: https:/ / ruralis.no/wp-content/uploads/2017/05/15899d28b5e765.pdf (accessed on 21 November 2018).

Heggestad, Anne Kari Tolo, Bente Høy, Berit Sæteren, Åshild Slettebø, Britt Lillestø, Arne Rehnsfeldt, Lillemor Lindwall, Vibeke Lohne, Maj-Britt Råholm, and Trygve Aas. 2015. Dignity, Dependence, and Relational Autonomy for Older People Living in Nursing Homes. International Journal of Human Caring 19: 42-46. [CrossRef]

Heijkenskjöld, Katarina Bredenhof, Mirjam Ekstedt, and Lillemor Lindwall. 2010. The Patient's Dignity from the Nurse's Perspective. Nursing Ethics 17: 313-24. [CrossRef] [PubMed]

Høeg, Ida M. 2010. Religion og alder [Religion and Age]. Kirke og Kultur, 331-37.

Jakobsen, Rita, and Venke Sørlie. 2010. Dignity of Older People in a Nursing Home: Narratives of Care Providers. Nursing Ethics 17: 289-300. [CrossRef] [PubMed]

Karlsson, Maud, and Ingegerd Bergbom. 2010. Being Cared for and Not Being Cared for-A Hermeneutical Interpretation of an Autobiography. International Journal for Human Caring 14: 58-65. [CrossRef]

Kenny, Gerard. 2011. Reflections on Love's Spirals. Journal of Holistic Nursing 29: 148-56. [CrossRef]

Lassenius, Erna. 2005. Rummet i Vårdandets Värld [The Space in the Caring Communion]. Ph.D. dissertation, Åbo Akademi University, Vasa, Finland.

Lavretsky, Helen. 2010. Spirituality and Aging. Aging Health 6: 749-69. [CrossRef]

Ledger, Sylvia D. 2005. Holistic Care. The Duty of Nurses to Meet Patients' Spiritual and/or Religious Needs. British Journal of Nursing 14: 220-25. [CrossRef] 
Levy-Malmberg, Rika, Katie Eriksson, and Lisbet Lindholm. 2008. Caritas-Caring as an Ethical Conduct. Scandinavian Journal of Caring Sciences 22: 662-67. [CrossRef]

Lewis, Lisa M., Sheila Hankin, Diane Reynolds, and Gbenga Ogedegbe. 2007. African American Spirituality: A Process of Honoring God, Others, and Self. Journal of Holistic Nursing 25: 16-23. [CrossRef]

Lindström, Unni Å., Lisbet Lindholm, and Joan E. Zetterlund. 2010. Katie Eriksson: Theory of Caritative Caring. In Nursing Theorists and Their Work. Edited by Ann Marriner-Tomey and Martha Raile Alligood. Maryland Heights: Mosby Elsevier, pp. 190-221.

MacKinlay, Elizabeth, and Rosalie Hudson. 2008. A Review of the Literature in 2006. International Journal of Older People Nursing 3: 139-44. [CrossRef] [PubMed]

Macklin, Ruth. 2003. Dignity is a Useless Concept. British Medical Journal 327: 1419-20. [CrossRef] [PubMed]

Malone, Joanna, and Anna Dadswell. 2018. The Role of Religion, Spirituality and/or Belief in Positive Ageing for Older Adults. Geriatrics 3: 28. [CrossRef]

Manthorpe, Jill, Steve Iliffe, Kritika Samsi, Laura Cole, Claire Goodman, Vari Drennan, and James Warner. 2010. Dementia, Dignity and Quality of Life: Nursing Practice and its Dilemmas. International Journal of Older People Nursing 5: 235-44. [CrossRef] [PubMed]

Miner-Williams, Denise. 2006. Putting a Puzzle Together: Making Spirituality Meaningful for Nursing Using an Evolving Theoretical Framework. Journal of Clinical Nursing 15: 811-21. [CrossRef] [PubMed]

Ministry of Health and Care Services. 2010. Forskrift om en Verdig Eldreomsorg (FOR-2010-11-12-1426) [Regulation on a Dignified Elderly Care]. Available online: https:/ /lovdata.no/forskrift/2010-11-12-1426 (accessed on 17 November 2018).

Nåden, Dagfinn, and Katie Eriksson. 2004. Understanding the Importance of Values and Moral Attitudes in Nursing Care in Preserving Human Dignity. Nursing Science Quarterly 17: 86-91. [CrossRef]

Nordenfelt, Lennart. 2003. Dignity of the Elderly: An Introduction. Medicine, Health and Philosophy 6: 99-101. [CrossRef]

Oosterveld-Vlug, Mariska G., H. Roeline W. Pasman, Isis E. van Gennip, Martien T. Muller, Dick L. Willems, and Bregje D. Onwuteaka-Philipsen. 2014. Dignity and the Factors That Influence it According to Nursing Home Residents: A Qualitative Interview Study. Journal of Advanced Nursing 70: 97-106. [CrossRef]

Otto, Rudolf. 1958. The Idea of the Holy. New York: Oxford University Press.

Paley, John. 2009. Doing Justice to the Complexities of Spirituality and Religion in a Pluralistic World. Journal of Clinical Nursing 18: 3512-13. [CrossRef]

Pesut, Barbara. 2008. A Conversation on Diverse Perspectives of Spirituality in Nursing Literature. Nursing Philosophy 9: 98-109. [CrossRef]

Pesut, Barbara, and Sheryl Reimer-Kirkham. 2010. Situated Clinical Encounters in the Negotiation of Religious and Spiritual Plurality: A Critical Ethnography. International Journal of Nursing Studies 47: 815-25. [CrossRef] [PubMed]

Pesut, Barbara, Marsha Fowler, Elizabeth J. Taylor, Sheryl Reimer-Kirkham, and Richard Sawatzky. 2008. Conceptualising Spirituality and Religion for Healthcare. Journal of Clinical Nursing 17: 2803-10. [CrossRef] [PubMed]

Phillips-Salimi, Celeste R., Joan E. Haase, and Wendy Carter Kooken. 2012. Connectedness in the Context of Patient-Provider Relationships: A Concept Analysis. Journal of Advanced Nursing 68: 230-45. [CrossRef] [PubMed]

Pleschberger, Sabine. 2007. Dignity and the Challenge of Dying in Nursing Homes: The Residents' View. Age and Ageing 36: 197-202. [CrossRef] [PubMed]

Råholm, Maj-Britt, and Katie Eriksson. 2001. Call to Life: Exploring the Spiritual Dimension as a Dialectic Between Suffering and Desire Experienced by Coronary Bypass Patients. International Journal for Human Caring 5: 14-20. [CrossRef]

Råholm, Maj-Britt, Lisbet Lindholm, and Katie Eriksson. 2002. Grasping the Essence of the Spriritual Dimension Reflected Through the Horizon of Suffering: An Interpretative Research Synthesis. The Australian Journal of Holistic Nursing 9: 4-13. [PubMed]

Reed, Pamela G. 1992. An Emerging Paradigm for the Investigation of Spirituality in Nursing. Research in Nursing $\mathcal{E}$ Health 15: 349-57. [CrossRef]

Register, M. Elizabeth, and JoAnne Herman. 2010. Quality of Life Revisited: the Concept of Connectedness in Older Adults. Advances in Nursing Science 33: 53-63. [CrossRef] [PubMed] 
Reyes, Darcel. 2012. Self-Compassion: A Concept Analysis. Journal of Holistic Nursing 30: 81-89. [CrossRef] [PubMed]

Ross, Linda A. 1997. Elderly Patients' Perceptions of Their Spiritual Needs and Care: A Pilot Study. Journal of Advanced Nursing 26: 710-15. [CrossRef] [PubMed]

Rykkje, Linda. 2014. Kjærlighet i Forbundethet: en Kraft i Gamle Menneskers Åndelighet Og Verdighet [Love in Connectedness: A Force in Older People's Spirituality and Dignity]. Ph.D. dissertation, Åbo Akademi University, Vasa, Finland.

Rykkje, Linda, and Maj-Britt Råholm. 2014. Understanding Older Peoples' Experiences of Dignity and its Significance in Caring-A Hermeneutical Study. International Journal for Human Caring 18: 17-26.

Rykkje, Linda, Katie Eriksson, and Maj-Britt Råholm. 2011. A Qualitative Metasynthesis of Spirituality from a Caring Science Perspective. International Journal for Human Caring 15: 40-53. [CrossRef]

Rykkje, Linda L. R., Katie Eriksson, and Maj-Britt Råholm. 2013. Spirituality and Caring in Old Age and the Significance of Religion-A Hermeneutical Study from Norway. Scandinavian Journal of Caring Sciences 27: 275-84. [CrossRef] [PubMed]

Rykkje, Linda, Katie Eriksson, and Maj-Britt Råholm. 2015. Love in Connectedness: A Theoretical Study. Sage Open 1-11. [CrossRef]

Šaňáková, Šárka, and Juraj Čáp. 2018. Dignity from the Nurses' and Older Patients' Perspective: A Qualitative Literature Review. Nursing Ethics [CrossRef]

Sartori, Penny. 2010. Spirituality 1: Should Spiritual and Religious Beliefs Be Part of Patient Care? Nursing Times 106: 14-17. [PubMed]

Sessanna, Loralee, Deborah Finnell, and Mary Ann Jezewski. 2007. Spirituality in Nursing and Health-Related Literature. Journal of Holistic Nursing 25: 252-62. [CrossRef] [PubMed]

Sessanna, Loralee, Deborah S. Finnell, Meghan Underhill, Yu-Ping Chang, and Hsi-Ling Peng. 2011. Measures Assessing Spirituality as More Than Religiosity: A Methodological Review of Nursing and Health-Related Literature. Journal of Advanced Nursing 67: 1677-94. [CrossRef]

Shotton, Leila, and David Seedhouse. 1998. Practical Dignity in Caring. Nursing Ethics 5: 246-55. [CrossRef] [PubMed]

Sinclair, Shane, Jill M. Norris, Shelagh J. McConnell, Harvey Max Chochinov, Thomas F. Hack, Neil A. Hagen, Susan McClement, and Shelley Raffin Bouchal. 2016. Compassion: A Scoping Review of the Healthcare Literature. BMC Palliative Care 15: 6. [CrossRef] [PubMed]

Singh, Pavneet, Shelley Raffin-Bouchal, Susan McClement, Thomas F. Hack, Kelli Stajduhar, Neil A. Hagen, Aynharan Sinnarajah, Harvey M. Chochinov, and Shane Sinclair. 2018. Healthcare Providers' Perspectives on Perceived Barriers and Facilitators of Compassion: Results from a Grounded Theory Study. Journal of Clinical Nursing 27: 2083-97. [CrossRef]

Sivonen, Kerstin. 2000. Vården och det Andliga. En Bestämning av Begreppet 'Andlig' ur ett Vårdvetenskapligt Perspektiv [Caring and the Spiritual. A Determination of the Concept 'Spirit' from a Caring Science Perspective]. Ph.D. dissertation, Åbo Akademi University, Vasa, Finland.

Stabell, Aase, and Unni Å. Lindström. 2003. Mot opplevelse av integriet og verdighet—En streben og strid? [Towards Integrity and Dignity-A Struggle and Fight?]. Vård i Norden 23: 29-34.

Stickley, Theodore, and Dawn Freshwater. 2002. The Art of Loving and the Therapeutic Relationship. Nursing Inquiry 9: 250-56. [CrossRef] [PubMed]

Straughair, Collette. 2012. Exploring Compassion: Implications for Contemporary Nursing. Part 1. British Journal of Nursing 21: 160-64. [CrossRef] [PubMed]

Sulmasy, Daniel P. 2013. The Varieties of Human Dignity: A Logical and Conceptual Analysis. Medicine, Health Care and Philosophy 16: 937-44. [CrossRef] [PubMed]

Swinton, John, and Stephen Pattison. 2010. Moving Beyond Clarity: Towards a Thin, Vague, and Useful Understanding of Spirituality in Nursing Care. Nursing Philosophy 11: 226-37. [CrossRef] [PubMed]

Tadd, Win, Tony Bayer, and Paul Dieppe. 2002. Dignity in Health Care: Reality or Rhetoric? Reviews in Clinical Gerontology 12: 1-4. [CrossRef]

Tauber-Gilmore, Marcelle, Gulen Addis, Zainab Zahran, Sally Black, Lesley Baillie, Sue Procter, and Christine Norton. 2018. The Views of Older People and Health Professionals about Dignity in Acute Hospital Care. Journal of Clinical Nursing 27: 223-34. [CrossRef] 
Taylor, Amy, Denyse Hodgson, Melanie Gee, and Karen Collins. 2017. Compassion in Healthcare: A Concept Analysis. Journal of Radiotherapy in Practice 16: 350-60. [CrossRef]

Thorkildsen, Kari Marie, Katie Eriksson, and Maj-Britt Råholm. 2013. The Substance of Love When Encountering Suffering: An Interpretative Research Synthesis with an Abductive Approach. Scandinavian Journal of Caring Sciences 27: 449-59. [CrossRef]

Tillich, Paul. 1954. Love, Power and Justice: Ontological Analyses and Ethical Applications. London: Oxford University Press.

Toivonen, Kristiina, Andreas Charalambous, and Riitta Suhonen. 2018. Supporting Spirituality in the Care of Older People Living with Dementia: A Hermeneutic Phenomenological Inquiry into Nurses' Experiences. Scandinavian Journal of Caring Sciences 32: 880-88. [CrossRef]

Torbjørnsen, Tor. 2008. Åndelig omsorg [Spiritual Care]. In Geriatrisk sykepleie: God Omsorg til den Gamle pasienten [Geriatric Nursing: Good Care for the Old Patient]. Edited by Marit Kirkevold, Kari Brodtkorb and Anette Hylen Ranhoff. Oslo: Gyldendal akademisk, pp. 456-64.

Tornøe, Kirsten. 1996. Kan vi Trøste Hjertene? Hvordan Møte Alvorlig Syke og Døendes Pasienters Åndelige behov [Can We Comfort the Hearts? How to Meet Sick and Dying Patients' Spiritual Needs]. Oslo: Tano.

Touhy, Theris A. 2001. Nurturing Hope and Spirituality in the Nursing Home. Holistic Nursing Practice 15: 45-56. [CrossRef]

Valizadeh, Leila, Vahid Zamanzadeh, Belinda Dewar, Azad Rahmani, and Mansour Ghafourifard. 2016. Nurse's Perceptions of Organisational Barriers to Delivering Compassionate Care: A Qualitative Study. Nursing Ethics 25: 580-90. [CrossRef] [PubMed]

van der Cingel, Margreet. 2011. Compassion in Care: A Qualitative Study of Older People with a Chronic Disease and Nurses. Nursing Ethics 18: 672-85. [CrossRef] [PubMed]

van Leeuwen, René, and Annemiek Schep-Akkerman. 2015. Nurses' Perceptions of Spirituality and Spiritual Care in Different Health Care Settings in the Netherlands. Religions 6: 1346. [CrossRef]

van Leeuwen, René, Lucas J. Tiesinga, Doeke Post, and H. Jochemsen. 2006. Spiritual Care: Implications for Nurses' Professional Responsibility. Journal of Clinical Nursing 15: 875-84. [CrossRef] [PubMed]

von Dietze, Erich, and Angelica Orb. 2000. Compassionate Care: A Moral Dimension of Nursing. Nursing Inquiry 7: 166-74. [CrossRef]

Wallace, Meredith, and Eileen O'Shea. 2007. Perceptions of Spirituality and Spiritual Care among Older Nursing Home Residents at the End of Life. Holistic Nursing Practice 21: 285-89. [CrossRef] [PubMed]

Whitehead, Brenda. 2018. Religiousness on Mental Health in Older Adults: the Mediating Role of Social Support and Healthy Behaviours. Mental Health, Religion \& Culture 21: 429-41. [CrossRef]

Whitehead, Juliet, and Herman Wheeler. 2008. Patients' Experiences of Privacy and Dignity. Part 1: A Literature Review. British Journal of Nursing 17: 381-85. [CrossRef]

WMA (World Medical Association). 2013. Declaration of Helsinki-Ethical Principles for Medical Research Involving Human Subjects. Available online: https:/ / www.wma.net/policies-post/wma-declaration-ofhelsinki-ethical-principles-for-medical-research-involving-human-subjects / (accessed on 9 December 2018).

Younger, Janet B. 1995. The Alienation of the Sufferer. Advances in Nursing Science 17: 53-72. [CrossRef]

Zimmer, Zachary, Carol Jagger, Chi-Tsun Chiu, Mary Beth Ofstedal, Florencia Rojo, and Yasuhiko Saito. 2016. Spirituality, Religiosity, Aging and Health in Global Perspective: A Review. SSM-Population Health 2: 373-81. [CrossRef]

(C) 2018 by the author. Licensee MDPI, Basel, Switzerland. This article is an open access article distributed under the terms and conditions of the Creative Commons Attribution (CC BY) license (http://creativecommons.org/licenses/by/4.0/). 